\title{
APLIKASI SISTEM PAKAR UNTUK MENDIAGNOSA PENYAKIT ISPA MENGGUNAKAN METODE NAIVE BAYES BERBASIS WEBSITE
}

\author{
Fikry Ramadhana ${ }^{1}$, Fauziah $^{2}$, Winarsih $^{3}$ \\ Fakultas Teknologi Komunikasi dan Informatika - Sistem Informasi, Universitas Nasional \\ fikryramadhana8@gmail.com ${ }^{1}$,fauziah@civitas.unas.ac.id ${ }^{2}$,winarsih@civitas.unas.ac.id ${ }^{3}$
}

Submitted December 21, 2019; Revised March 7, 2020; Accepted March 28, 2020

\begin{abstract}
Abstrak
ISPA (Infeksi Saluran Pernafasan Akut) adalah suatu penyakit yang timbul akibat gangguan saluran pernafasan yang dapat menyebabkan berbagai macam penyakit mulai dari penyakit tanpa gejala, infeksi ringan hingga berat akibat dari faktor lingkungan. Kurangnya pengetahuan masyarakat mengenai gejala, cara penanganan serta cara mengatasi nya, mengakibatkan angka kematian yang cukup tinggi akibat ISPA. Sistem pakar yang akan dibuat diperuntukkan untuk memudahkan seseorang dalam melakukan diagnosa penyakit ISPA dengan cara mengadopsi pengetahuan manusia ke dalam sistem komputer sehingga sistem pakar mampu menyelesaikan permasalahan seperti yang dilakukan seorang pakar. Aplikasi sistem pakar yang dibuat menggunakan metode Naive Bayes dikarenakan metode Naive Bayes merupakan metode klasifikasi terbaik dengan probabilitas yang tinggi ketika digunakan dalam perhitungan sistem nya. Dengan aplikasi ini seseorang akan merasa seperti sedang berkonsultasi dengan seorang dokter atau pakar yang menangani penyakit ISPA. Aplikasi ini dibangun berbasis website dengan menggunakan bahasa pemrograman PHP, framework Codeigniter dan database MySQL. Terdapat data latih sebanyak 104 data dan telah dilakukan pengujian sebanyak 39 data uji. Dari 39 kali pengujian terdapat 36 data uji yang sesuai dan ada 3 data uji yang tidak sesuai. Diperoleh akurasi dari pengujian tersebut sebesar 92,3\%.
\end{abstract}

Kata Kunci : Sistem pakar, ISPA, metode Naive Bayes.

\begin{abstract}
ISPA (Acute Respiratory Infection) is a disease that occurs due to respiratory tract disorders that can cause a variety of diseases ranging from asymptomatic illnesses, mild to severe infections due to environmental factors. The lack of public knowledge about the symptoms, how to treat it and how to overcome it result in a fairly high mortality rate due to ISPA. The expert system to be created is intended to make it easier a person to diagnose ISPA by adopting human knowledge into a computer system so the expert system is able to solve problems like an expert does. Expert system application is made using the Naive Bayesmethod because the Naive Bayesmethod is the best classification method with high probability when used in its system calculation. With this application, people will feel like they are consulting with a doctor or an expert who handles ISPA. This application is built based on websites that use the PHP programming language, Codeigniter framework and MySQL database. There are 104 training data and 39 testing data that have been tested. From 39 tests, there are 36 test data that are suitable and there are 3 test data that are not suitable. Accuracy obtained from the test is of $92.3 \%$.
\end{abstract}

Keywords : Expert system, ISPA, Naive Bayes method.

\section{PENDAHULUAN}

Perkembangan teknologi informasi pada saat ini sangat pesat dan telah digunakan dalam banyak bidang seperti perbankan, pemerintahan, industri, pendidikan, bahkan kesehatan. Dalam bidang kesehatan, perkembangan teknologi informasi memiliki peran signifikan dalam penanganan berbagai penyakit salah satunya adalah ISPA (Infeksi Saluran Pernafasan Akut). Dibutuhkan sebuah sistem yang dapat memberikan kemudahan bagi masyarakat untuk mengetahui dan 
menyadari deteksi awal penyakit ISPA. Sehingga masyarakat bisa mengetahui tindakan pertama yang harus dilakukan sebelum ke dokter untuk penanganan lebih lanjut.

Dengan latar belakang tersebut diperlukan sistem yang dapat memberikan diagnosa terkait dengan penyakit ISPA yang kemampuan nya seolah mirip seorang pakar. Sistem pakar merupakan sistem yang menggunakan pengetahuan manusia yang dimasukkan ke dalam sistem komputer untuk memecahkan masalah layaknya seorang pakar. Pada penelitian sebelumnya terkait dengan sistem pakar diagnosis penyakit ISPA berbasis speech recognition menggunakan metode naive bayes classifier berbasis android dapat mengklaster jawaban user berdasar rules yang dibuat sehingga mendapatkan hasil diagnosa [1]. Selain itu pada penelitian implementasi metode naive bayes pada aplikasi prediksi penyebaran wabah penyakit ISPA berbasis desktop memaparkan rekap laporan penyebaran wabah penyakit ISPA di kota Pontianak tiap bulan dan tahun nya [2].

Dari penelitian sebelumnya yang serupa memiliki 9 jenis penyakit ISPA, sedangkan pada penelitian ini hanya 6 dikarenakan jenis penyakit yang ada pada penelitian sebelumnya termasuk ke gejala penyakit ISPA bukan jenis penyakit ISPA.

Batasan masalah dari perancangan sistem pakar ini yaitu mampu menerapkan kemampuan seorang pakar dalam sistem komputer yang membantu mendiagnosa penyakit ISPA serta menerapkan metode naive bayes pada sistem yang dibuat.

Penulis mendapatkan 15 jurnal acuan berkaitan dengan tema yang penulis sedang teliti.Jurnal acuan pertama dibuat oleh Mariam Marlina, Wiwin Saputra, Bohati Mulyadi, Bismi Hayati, dan Jaroji yang membahas mengenai aplikasi sistem pakar diagnosis penyakit ispa berbasis speech recognition menggunakan metode naive bayes classifier dimana dalam menjawab pertanyaan-pertanyaan diagnosa menggunakan suara, tetapi pada jurnal acuan ini tidak disebutkan prosentase akurasi menggunakan metode Naive Bayes[1].

Mengacu pada jurnal penelitian kedua dapat disimpulkan bahwa aplikasi prediksi penyebaran wabah ISPA di kota Pontianak yang menggunakan metode Naive Bayes mendapat nilai akurasi sebesar $82,97 \%$ dari data 23 puskesmas yang menggunakan data uji pada tahun 2017 [2].

Mengacu pada jurnal penelitian ketiga dapat disimpulkan bahwa penelitian tersebut membuat sebuah sistem pakar untuk mendeteksi awal penyakit tuberkulosis yang menggunakan metode Naive Bayes dan mempunyai prosentase akurasi $71,32 \%$ diambil dari data latih satu orang yang didiagnosa menderita penyakit tuberkulosis [3].

Mengacu pada jurnal penelitian keempat dapat disimpulkan bahwa sistem dibuat untuk mendiagnosa penyalahgunaan narkoba yang menggunakan metode Naive Bayes mempunyai hasil pengujian dengan data 30 orang dan didapatkan nilai akurasi $80 \%$ [4].

Mengacu pada jurnal penelitian kelima dapat disimpulkan bahwa dalam pembuatan sistem pakar yang digunakan untuk mendiagnosa penyakit diabetes menggunakan metode Naive Bayes dan certainty factor ini mendapatkan keakuratan data $100 \%$ dari 30 data latih dengan sample uji di RSUD Bendan Pekalongan [5].

Mengacu pada jurnal penelitian keenam dapat disimpulkan bahwa sistem yang dibuat tersebut adalah sistem klasifikasi untuk mendiagnosa penyakit jantung dari dokumen kesehatan menggunakan metode Naive Bayes classifier yang menghasilkan 
keakuratan data mencapai $83,7 \%$ dari 226 data pasien [6].

Mengacu pada jurnal penelitian ketujuh dapat disimpulkan bahwa penelitian yang dilakukan adalah untuk memprediksi penyakit mesothelioma menggunakan metode EM (Expectation Maximization) dan metode Naive Bayes yang mendapatkan hasil keakuratan data mencapai 93,21\% dalam memprediksi penyakit yang diteliti [7].

Mengacu pada jurnal penelitian kedelapan dapat disimpulkan bahwa penelitian yang dilakukan untuk melakukan diagnosa penyakit jagung di Bangkalan dengan menggunakan metode Naive Bayes dan certainty factor menghasilkan prosentase $80 \%$ dalam mendiagnosis dari 15 data yang ada [8].

Mengacu pada jurnal penelitian kesembilan dapat disimpulkan bahwa penelitian ini dilakukan untuk memprediksi tingkat gangguan hiperaktif dan kurangnya perhatian pada masa kecil menggunakan metode Naive Bayes yang menghasilkan keakuratan hasil sebesar $88,62 \%$ pada sistem pakar yang dibuat [9].

Tujuan dari penelitian ini adalah terciptanya sebuah sistem yang dapat mendiagnosa penyakit ISPA layaknya seorang pakar. Dengan menerapkan metode Naive Bayes ke dalam sistem pakar diagnosa penyakit ISPA diharapkan dapat membantu masyarakat dalam mendiagnosa penyakit ISPA

\section{METODE PENELITIAN}

Agar mudah dipahami maka penulis memaparkan metodelogi penelitian menggunakan flowchart sebagai berikut:

\section{Flowchart Perancangan Penelitian}

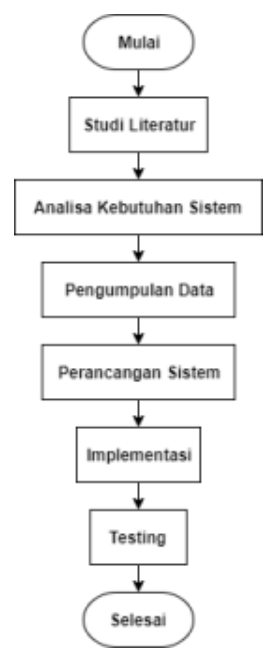

Gambar 1. Flowchart Perancangan Sistem

Pada gambar 1 menunjukkan alur dari perancangan penelitian. Perancangan penelitian dilakukan dalam beberapa tahapan, antara lain:

1. Studi Literatur

Pada tahap ini menjadi salah satu tahap dalam mendapatkan informasi berupa jurnal ilmiah, buku dan sumber referensi lainnya terkait penelitian ini.

2. Analisa Kebutuhan Sistem

Setelah mencari jurnal, buku, dan referensi lain yang terkait, selanjutnya menentukaan kebutuhan yang akan digunakan dalam penelitian baik tools, bahasa pemrograman, metode dan juga database yang akan digunakan dalam perancangan sistem.

3. Pengumpulan Data

Dalam tahap ini peneliti melakukan pencarian data yang dilakukan melalui proses wawancara pakar, dan juga studi pustaka. Peneliti mengumpulkan data-data berupa jenis penyakit, gejala penyakit, dan juga aturan atau rule naive bayes.

4. Perancangan Sistem

Merupakan tahap pembuatan sistem secara menyeluruh baik dari desain aplikasi maupun coding. 
5. Implementasi

Merupakan proses penerapan atau pengujian sistem apakah sudah sesuai dengan rancangan yang telah didesain atau belum.

6. Testing

Pada tahap ini merupakan tahapan proses uji sistem mulai dari fungsional sistem dan akurasi sistem terhadap hasil pakar.

\section{Perancangan Use Case Diagram Sistem}

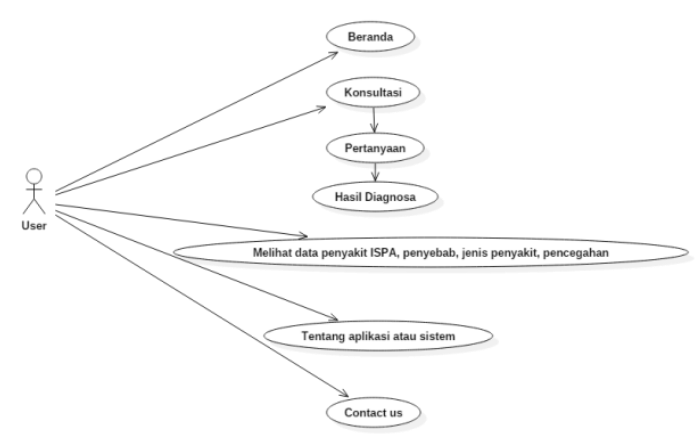

Gambar 2. Use Case Diagram Sistem

Perancangan yang digunakan untuk membangun sistem pakar penyakit ISPA adalah perancangan UML sehingga mempermudah visualisasi dalam pembuatan aplikasi.

- User

Pada aplikasi yang dibuat user hanya dapat mengakses halaman home, melakukan konsultasi dan melihat diagnosa atau hasil konsultasi.

- Admin

Admin dapat mengakses fitur-fitur yang user bisa akses, dan admin memiliki fitur tambahan yaitu dashboard yang terdapat menu antara lain gejala, penyakit, data latih, data pengujian. Admin hanya bisa mengedit gejala dan penyakit.

\section{Metode Naive Bayes}

Metode naive bayes merupakan salah satu cara untuk mengatasi ketidakpastian data dengan metode probabilistik pengklasifikasian sederhana berdasar teorema bayes melalui data latih dari sejumlah data secara efisien.

Perhitungan metode Naive Bayes dapat dilakukan dengan menggunakan langkahlangkah berikut ini [16]:

1. Menghitung jumlah class $\mathrm{P}(\mathrm{H})$

2. Menghitung jumlah kasus yang sama dengan class yang sama $\mathrm{P}(\mathrm{X} \mid \mathrm{H})$

3. Mengkalikan semua hasil $\mathrm{P}(\mathrm{X} \mid \mathrm{H})$ dengan jumlah class masing-masing.

4. Menentukan presentase nilai prediksi kategori.

Dalam prosesnya rumus probabilitas dijelaskan pada persamaan 1, sebagai berikut:

$$
P(H \mid X)=\frac{P(X \mid H) P(H)}{P(X)}
$$

\begin{tabular}{|c|c|}
\hline Parameter & Keterangan \\
\hline $\mathrm{P}(\mathrm{H} \mid \mathrm{X})$ & $\begin{array}{l}\text { Probabilitas akhir bersyara } \\
\text { suatu hipotesis } \mathrm{H} \text { terjad } \\
\text { jika diberikan bukti } \mathrm{X} \\
\text { terjadi. }\end{array}$ \\
\hline $\mathrm{P}(\mathrm{X} \mid \mathrm{H})$ & $\begin{array}{l}\text { Probabilitas sebuah bukti } X \\
\text { terjadi akan mempengaruh } \\
\text { hipotesis H (probabilitas } \\
\text { posterior). }\end{array}$ \\
\hline $\mathrm{P}(\mathrm{H})$ & $\begin{array}{l}\text { Probabilitas awal (prior) } \\
\text { hipotesis H terjadi tanpa } \\
\text { memandang bukti apapun. }\end{array}$ \\
\hline $\mathrm{P}(\mathrm{X})$ & $\begin{array}{l}\text { Probabilitas awal (prior) } \\
\text { bukti X terjadi tanpa } \\
\text { memandang hipotesis bukti } \\
\text { yang lain. }\end{array}$ \\
\hline
\end{tabular}




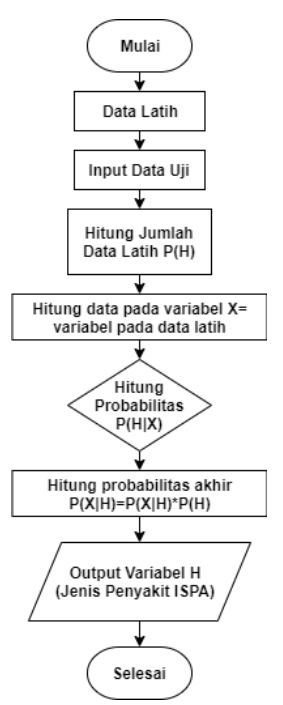

\section{Gambar 3. Flowchart Naive Bayes}

Pada gambar 3 menjelaskan tentang alur perhitungan naive bayes dimana langkah pertama yaitu menginput data latih serta menginput data uji. Langkah selanjutnya menghitung jumlah data latih, menghitung data variable pada data latih, menghitung probabilitas jumlah data latih, dan menghitung probabilitas akhir untuk menghasilkan output variabel jenis penyakit ISPA. Maka akan dilakukan suatu proses perhitungan dari data sebelumnya yang sudah ada dengan menggunakan metode Naive Bayes untuk mendapatkan informasi tentang klasifikasi class penyakit.

\section{Flowchart Sistem}

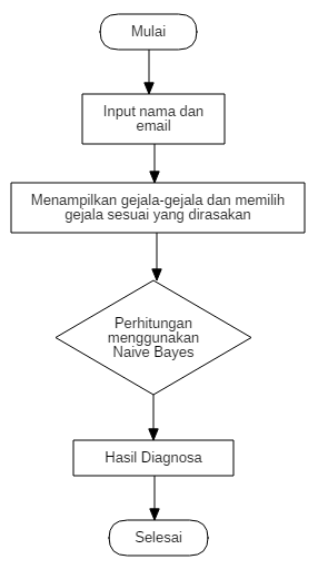

Gambar 4. Flowchart Sistem
Pada gambar 4 merupakan flowchart sistem secara garis besar. Sistem akan menampilkan seluruh gejala-gejala yang ada tiap jenis penyakit ISPA lalu user memilih gejala yang dialami oleh penderita yang diduga mengidap penyakit ISPA dan setelah itu akan diproses menggunakan perhitungan Naive Bayes sehingga menghasilkan output diagnosa jenis penyakit ISPA oleh penderita.

\section{Akurasi Sistem}

Setelah perhitungan menggunakan metode Naive Bayes, terdapat hasil-hasil dari pengujian sistem. Untuk mengetahui keakuratan sistem, digunakan perhitungan sebagai berikut:

$$
\text { Akurasi }=\frac{\text { Banyak data yang sesuai }}{\text { Banyak jumlah data uji }} 100 \%
$$

\section{HASIL DAN PEMBAHASAN}

\section{Analisa Data}

Proses untuk menentukan jenis penyakit ISPA dalam sistem menggunakan metode Naive Bayes. Berdasarkan pada pengetahuan pakar dari proses wawancara. terdapat enam jenis penyakit ISPA seperti pada tabel di bawah.

Tabel 1. Jenis Penyakit

\begin{tabular}{ll}
\hline Kode Penyakit & \multicolumn{1}{c}{ Jenis Penyakit } \\
\hline P1 & Sinusitis \\
\hline P2 & $\begin{array}{l}\text { Tonsilitis, Faringitis, Laringitis } \\
\text { (Radang Tenggorokan) }\end{array}$ \\
\hline P3 & Bronkitis \\
\hline P4 & Bronkiolitis \\
\hline P5 & Pneumonia \\
\hline P6 & Pleuritis \\
\hline
\end{tabular}

Keterangan:

- Sinusitis : Inflamasi atau peradangan pada dinding sinus.

- Radang Tenggorokan : Peradangan dan pembengkakan yang terjadi pada amandel. Peradangan umumnya disebabkan oleh infeksi.

- Bronkitis : Peradangan yang terjadi pada saluran utama pernapasan atau bronkus. 
- Bronkiolitis : Infeksi saluran napas yang menyebabkan terjadinya radang dan penyumbatan di dalam bronkiolus atau saluran pernapasan kecil di dalam paruparu.

- Pneumonia : Yang dikenal juga dengan paru-paru basah adalah infeksi yang mengakibatkan peradangan pada kantong-kantong udara di salah satu atau kedua paru-paru.

- Pleuritis : Peradangan pada selaput pembungkus organ paru-paru atau pleura.

Tabel 2. Gejala Penyakit

\begin{tabular}{ll}
\hline \multicolumn{1}{c}{ GEJALA } & $\begin{array}{c}\text { KODE } \\
\text { GEJALA }\end{array}$ \\
\hline Demam ringan & G01 \\
\hline Demam tinggi & G02 \\
\hline Hidung mampet & G03 \\
\hline Hidung berair atau beringus & G04 \\
\hline Ingus berwarna hijau atau kuning & G05 \\
\hline Sesak napas & G06 \\
\hline Frekuensi bernapas lebih cepat & G07 \\
\hline $\begin{array}{l}\text { Indera penciuman memburuk (Sulit } \\
\text { menangkap bau) }\end{array}$ & $\mathrm{G} 08$ \\
\hline Sakit kepala atau pusing & $\mathrm{G} 09$ \\
\hline Batuk-batuk & $\mathrm{G} 10$ \\
\hline Batuk kering & $\mathrm{G} 11$ \\
\hline $\begin{array}{l}\text { Batuk disertai dengan dahak } \\
\text { berwarna kuning keabu-abuan atau } \\
\text { hijau }\end{array}$ & $\mathrm{G} 12$ \\
\hline Batuk darah & $\mathrm{G} 13$ \\
\hline Batuk lebih dari 3 minggu & $\mathrm{G} 14$ \\
\hline $\begin{array}{l}\text { Sakit tenggorokan dan susah } \\
\text { menelan }\end{array}$ & $\mathrm{G} 15$ \\
\hline Suara serak & $\mathrm{G} 16$ \\
\hline Amandel merah dan bengkak & $\mathrm{G} 17$ \\
\hline Mulut bau & $\mathrm{G} 18$ \\
\hline Wajah terasa nyeri atau tertekan & $\mathrm{G} 19$ \\
\hline $\begin{array}{l}\text { Sakit atau rasa tidak nyaman pada } \\
\text { dada }\end{array}$ & $\mathrm{G} 20$ \\
\hline $\begin{array}{l}\text { Nyeri di dada ketika menarik napas } \\
\text { atau batuk }\end{array}$ & $\mathrm{G} 21$ \\
\hline Nyeri di bahu dan punggung & $\mathrm{G} 22$ \\
\hline Nyeri sendi dan otot & $\mathrm{G} 23$ \\
\hline Berkeringat dan menggigil & $\mathrm{G} 24$ \\
\hline Detak jantung menjadi cepat & $\mathrm{G} 25$ \\
\hline Mual dan muntah & $\mathrm{G} 26$ \\
\hline Selera makan menurun & $\mathrm{G} 27$ \\
\hline Berat badan menurun & $\mathrm{G} 28$ \\
\hline Lesu dan lemas & $\mathrm{G} 29$ \\
\hline $\begin{array}{l}\text { Kepat lelah } \\
\text { bibir dan kuku? }\end{array}$ & $\mathrm{G} 30$ \\
\hline
\end{tabular}

Pada tabel 2 menjelaskan gejala yang didapat dari pakar pada penyakit Sinusitis, Tonsilitis/ Faringitis /Laringitis (Radang Tenggorokan), Bronkitis, Bronkiolitis, Pneumonia, Pleuritis.

Tabel 3. Rules

\begin{tabular}{lc}
\hline \multicolumn{1}{c}{ IF } & THEN \\
\hline G01,G03,G05,G08,G10,G18,G19,G30 & P1 \\
\hline G01,G09,G10,G15,G16,G17,G29 & P2 \\
\hline $\begin{array}{l}\text { G01,G03,G04,G06,G12,G13,G14,G15,G } \\
\text { 20,G30 }\end{array}$ & P3 \\
\hline G01,G03,G04,G06,G07,G10,G31 & P4 \\
\hline $\begin{array}{l}\text { G01,G06,G11,G12,G13,G21,G24,G25,G } \\
\text { 26,G27,G29 }\end{array}$ & P5 \\
\hline G02,G06,G09,G11,G22,G23,G24,G27,G & P6 \\
\hline
\end{tabular}

Pada tabel 3 menjelaskan tentang aturan gejala berdasar setiap class penyakit menurut pakar dan dari jurnal acuan.

\section{Perhitungan Manual}

Berikut ini merupakan contoh kasus perhitungan manual dari salah satu pengujian oleh user dengan menginput beberapa gejala penyakit adalah sebagai berikut:

Tabel 4. Contoh Kasus

\begin{tabular}{cccc}
\hline Gejala & Pilihan & Gejala & Pilihan \\
\hline G01 & Ya & G17 & Tidak \\
\hline G02 & Tidak & G18 & Ya \\
\hline G03 & Ya & G19 & Ya \\
\hline G04 & Tidak & G20 & Tidak \\
\hline G05 & Ya & G21 & Tidak \\
\hline G06 & Tidak & G22 & Tidak \\
\hline G07 & Tidak & G23 & Tidak \\
\hline G08 & Ya & G24 & Tidak \\
\hline G09 & Tidak & G25 & Tidak \\
\hline G10 & Ya & G26 & Tidak \\
\hline G11 & Tidak & G27 & Tidak \\
\hline G12 & Tidak & G28 & Tidak \\
\hline G13 & Tidak & G29 & Tidak \\
\hline G14 & Tidak & G30 & Ya \\
\hline G15 & Tidak & G31 & Tidak \\
\hline G16 & Tidak & & \\
\cline { 1 - 2 } & & &
\end{tabular}

Setelah mendapat contoh kasus, maka langkah selanjutnya adalah: 
1. Menghitung jumlah class $\mathrm{P}(\mathrm{H})$ Jumlah data sinusitis, radang tenggorokan, bronkitis, bronkilitis, pneumonia, dan pleuritis pada data latih berbanding dengan jumlah data latih secara keseluruhan.

Tabel 5. Jumlah class

\begin{tabular}{|c|c|}
\hline \multicolumn{2}{|c|}{ Jumlah class $(\mathrm{H}=$ Penyakit) } \\
\hline $\mathrm{P}(\mathrm{H}=$ Sinusitis $)$ & $16 / 104=0,154$ \\
\hline $\begin{array}{l}\mathrm{P}(\mathrm{H}=\text { Tonsilitis, Faringitis, } \\
\text { Laringitis } \\
\text { Tenggorokan)) }\end{array}$ & $14 / 104=0,135$ \\
\hline $\mathrm{P}(\mathrm{H}=$ Bronkitis $)$ & $20 / 104=0,192$ \\
\hline $\mathrm{P}(\mathrm{H}=$ Bronkiolitis $)$ & $14 / 104=0,135$ \\
\hline $\mathrm{P}(\mathrm{H}=$ Pneumonia $)$ & $22 / 104=0,211$ \\
\hline $\mathrm{P}(\mathrm{H}=$ Pleuritis $)$ & $18 / 104=0,173$ \\
\hline
\end{tabular}

2. Menghitung jumlah kasus yang sama dengan class yang sama $\mathrm{P}(\mathrm{X} \mid \mathrm{H})$

Tabel 6. Jumlah kasus dan class yang sama

\begin{tabular}{|c|c|}
\hline & Demam ringan \\
\hline \multirow{6}{*}{ G01 } & $\mathrm{P}(\mathrm{G} 01=\mathrm{Ya} \mid \mathrm{H}=$ Sinusitis $)=8 / 16=0.5$ \\
\hline & $\begin{array}{l}\mathrm{P}(\mathrm{G} 01=\mathrm{Ya} \mid \mathrm{H}=\text { Radang Tenggorokan }) \\
=7 / 14=0.5\end{array}$ \\
\hline & $\mathrm{P}(\mathrm{G} 01=\mathrm{Ya} \mid \mathrm{H}=$ Bronkitis $)=10 / 20=0.5$ \\
\hline & $\mathrm{P}(\mathrm{G} 01=\mathrm{Ya} \mid \mathrm{H}=$ Bronkiolitis $)=7 / 14=0.5$ \\
\hline & $\mathrm{P}(\mathrm{G} 01=\mathrm{Ya} \mid \mathrm{H}=$ Pneumonia $)=11 / 22=0.5$ \\
\hline & $\mathrm{P}(\mathrm{G} 01=\mathrm{Ya} \mid \mathrm{H}=\mathrm{Pleuritis})=1 / 18=0.055$ \\
\hline & Demam tinggi \\
\hline \multirow{7}{*}{ G02 } & $\mathrm{P}(\mathrm{G} 02=$ Tidak $\mid \mathrm{H}=$ Sinusitis $)=15 / 16=0.9375$ \\
\hline & P(G02=Tidak $\mid \mathrm{H}=$ RadangTenggorokan $)$ \\
\hline & $=13 / 14=0,9285$ \\
\hline & $\mathrm{P}(\mathrm{G} 02=$ Tidak $\mid \mathrm{H}=$ Bronkitis $)=19 / 20=0.95$ \\
\hline & $\begin{array}{l}\mathrm{P}(\mathrm{G} 02=\text { Tidak } \mid \mathrm{H}=\text { Bronkiolitis })=13 / 14= \\
0,9285\end{array}$ \\
\hline & $\begin{array}{l}\mathrm{P}(\mathrm{G} 02=\text { Tidak } \quad \mathrm{H}=\text { Pneumonia })=21 / 22= \\
0.9545\end{array}$ \\
\hline & $\mathrm{P}(\mathrm{G} 02=$ Tidak $\mid \mathrm{H}=$ Pleuritis $)=9 / 18=0.5$ \\
\hline & Hidung mampet \\
\hline \multirow{6}{*}{ G03 } & $\mathrm{P}(\mathrm{G} 03=\mathrm{Ya} \mid \mathrm{H}=$ Sinusitis $)=8 / 16=0.5$ \\
\hline & $\begin{array}{l}\mathrm{P}(\mathrm{G} 03=\mathrm{Ya} \mid \mathrm{H}=\text { Radang Tenggorokan }) \\
=1 / 14=0,0714\end{array}$ \\
\hline & $\mathrm{P}(\mathrm{G} 03=\mathrm{Ya} \mid \mathrm{H}=$ Bronkitis $)=10 / 20=0.5$ \\
\hline & $\mathrm{P}(\mathrm{G} 03=\mathrm{Ya} \mid \mathrm{H}=$ Bronkiolitis $)=7 / 14=0,5$ \\
\hline & $\mathrm{P}(\mathrm{G} 03=\mathrm{Ya} \mid \mathrm{H}=$ Pneumonia $)=1 / 22=0.0454$ \\
\hline & $\mathrm{P}(\mathrm{G} 03=\mathrm{Ya} \mid \mathrm{H}=\mathrm{Pleuritis})=1 / 18=0.5555$ \\
\hline & Hidung berair atau beringus \\
\hline \multirow{6}{*}{ G04 } & $\mathrm{P}(\mathrm{G} 04=$ Tidak $\mid \mathrm{H}=$ Sinusitis $)=15 / 16=0.9375$ \\
\hline & $\begin{array}{l}\mathrm{P}(\mathrm{G} 04=\text { Tidak } \mid \mathrm{H}=\text { Radang Tenggorokan })= \\
13 / 14=0,9285\end{array}$ \\
\hline & $\mathrm{P}(\mathrm{G} 04=$ Tidak $\mid \mathrm{H}=$ Bronkitis $)=10 / 20=0.5$ \\
\hline & $\mathrm{P}(\mathrm{G} 04=$ Tidak $\mid \mathrm{H}=$ Bronkiolitis $)=7 / 14=0,5$ \\
\hline & $\begin{array}{l}\mathrm{P}(\mathrm{G} 04=\text { Tidak } \mid \mathrm{H}=\text { Pneumonia })=21 / 22= \\
0.9545\end{array}$ \\
\hline & $\mathrm{P}(\mathrm{G} 04=$ Tidak $\mid \mathrm{H}=$ Pleuritis $)=17 / 18=0.9444$ \\
\hline
\end{tabular}

\begin{tabular}{|c|c|}
\hline & Ingus berwarna hijau atau kuning \\
\hline \multirow{7}{*}{ G05 } & $\mathrm{P}(\mathrm{G} 05=\mathrm{Ya} \mid \mathrm{H}=$ Sinusitis $)=8 / 16=0.5$ \\
\hline & $\mathrm{P}(\mathrm{G} 05=\mathrm{Ya} \mid \mathrm{H}=$ Radang Tenggorokan $)$ \\
\hline & $=1 / 14=0,0714$ \\
\hline & $\mathrm{P}(\mathrm{G} 05=\mathrm{Ya} \mid \mathrm{H}=$ Bronkitis $)=1 / 20=0.05$ \\
\hline & $\mathrm{P}(\mathrm{G} 05=\mathrm{Ya} \mid \mathrm{H}=$ Bronkiolitis $)=1 / 14=0,0714$ \\
\hline & $\mathrm{P}(\mathrm{G} 05=\mathrm{Ya} \mid \mathrm{H}=$ Pneumonia $)=1 / 22=0.0454$ \\
\hline & $\mathrm{P}(\mathrm{G} 05=\mathrm{Ya} \mid \mathrm{H}=\mathrm{Pleuritis})=1 / 18=0.5555$ \\
\hline
\end{tabular}

Pada tabel 6, perhitungan setiap gejala. Penulis hanya melampirkan 5 perhitungan dari 31 perhitungan gejala yang menghasilkan nilai probabilitas dari setiap class penyakit berdasarkan gejala yang dialami.

3. Mengkalikan semua hasil Sinusitis, Radang Tenggorokan, Bronkitis, Bronkiolitis, Pneumonia, dan Pleuritis dengan jumlah class masing-masing.

Tabel 7. Hasil kali Penyakit

\begin{tabular}{lc}
\hline \multicolumn{1}{c}{ Penyakit } & \multicolumn{1}{c}{ Hasil Perkalian } \\
\hline Sinusitis & 0.000136202799851804 \\
\hline $\begin{array}{l}\text { Radang } \\
\text { Tenggorokan }\end{array}$ & 0.000000000036795288 \\
\hline Bronkitis & 0.000000000023247000 \\
\hline Bronkiolitis & 0.000000000478338750 \\
\hline Pneumonia & 0.000000000000022618 \\
\hline Pleuritis & 0.000000000000013780 \\
\hline
\end{tabular}

Pada tabel 7 merupakan hasil kali dari setiap class dengan jumlah class. Dari hasil tersebut diperoleh kesimpulan yaitu contoh kasus yang diuji, nilai probabilitas tertinggi adalah Sinusitis. Maka dapat disimpulkan bahwa klasifikasi penyakit yang diderita adalah Sinusitis.

\section{Interface Aplikasi}

Desain tampilan sistem pakar diagnosa penyakit ISPA menggunakan metode Naive Bayes berbasis website seperti pada gambar di bawah.

1. Halaman Home

Halaman home memuat beberapa konten seperti penjelasan mengenai aplikasi, tentang penyakit ISPA, form konsultasi untuk menuju ke halaman konsultasi, about untuk pengenalan 
aplikasi secara detail dan juga profil peneliti, dan footer dari aplikasi.

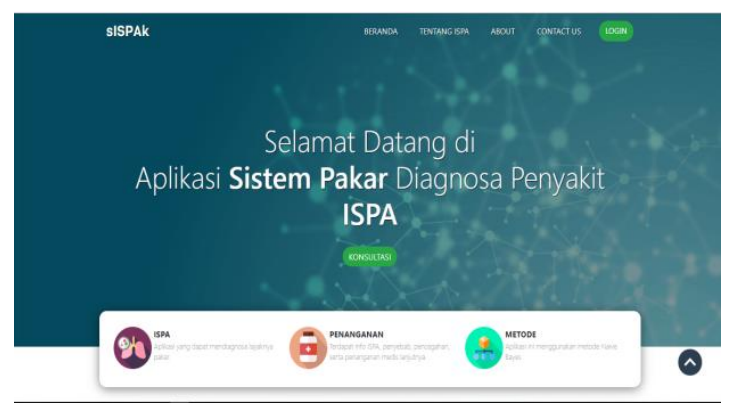

Gambar 5. Halaman Home

2. Halaman Konsultasi

Halaman konsultasi merupakan halaman yang akan digunakan oleh user untuk melakukan konsultasi keluhan yang dirasakan.

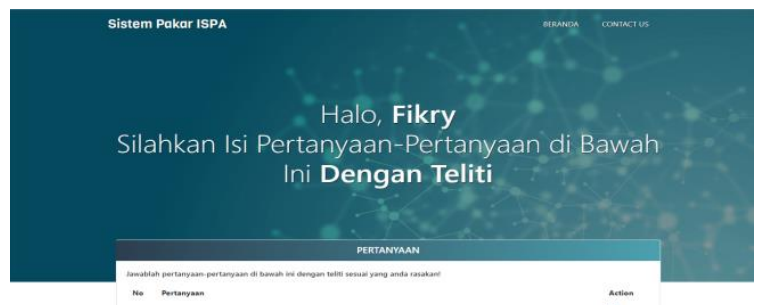

Gambar 6. Halaman Konsultasi

3. Halaman Hasil Konsultasi

Halaman hasil konsultasi merupakan halaman yang menampilkan diagnosa jenis penyakit diderita oleh user atau pasien.

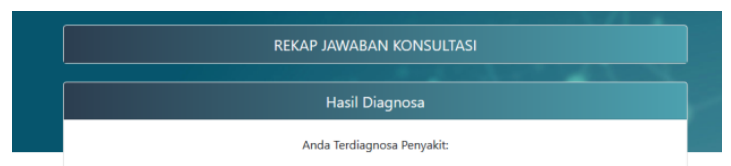

Sinusitis

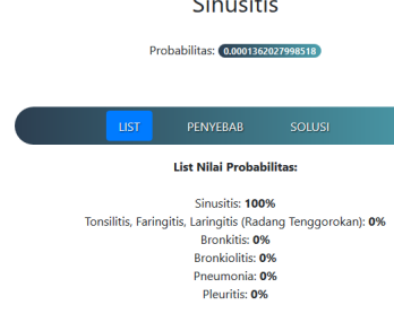

Gambar 7. Halaman Konsultasi

\section{Pengujian Sistem dengan Pakar}

Sistem pakar merupakan sistem yang menggunakan pengetahuan manusia yang dimasukkan ke dalam sistem komputer untuk memecahkan masalah layaknya seorang pakar. Setelah mendapatkan pengetahuan dari seorang pakar, untuk menguji sistem apakah berjalan dengan baik atau tidak, peneliti membuat data pengujian yang mengadopsi pengetahuan pakar dengan sistem yang peneliti buat. Peneliti membuat kuisioner dalam melakukan pengujian ini sebagai berikut:

Tabel 8. Pengujian Sistem dan Pakar

\begin{tabular}{clccc}
\hline No & \multicolumn{1}{c}{ Gejala } & Pakar & Sistem & Ket \\
\hline 1. & G05,G08,G30 & P01 & P01 & $\sqrt{ }$ \\
\hline 2. & G01,G15,G16 & P02 & P02 & $\sqrt{ }$ \\
\hline 3. & G14,G20,G30 & P03 & P03 & $\sqrt{ }$ \\
\hline 4. & G01,G04,G07 & P05 & P04 & \\
\hline 5. & G01,G21,G24 & P05 & P05 & $\sqrt{ }$ \\
\hline 6. & G02,G22,G27 & P06 & P06 & $\sqrt{ }$ \\
\hline 7. & G01,G15,G17 & P02 & P02 & $\sqrt{ }$ \\
\hline 8. & G03,G08,G18, & P01 & P01 & $\sqrt{ }$ \\
\hline 9. & G01,G14,G20 & P03 & P03 & $\sqrt{ }$ \\
\hline 10. & $\begin{array}{l}\text { G01,G06,G07, } \\
\text { G31 }\end{array}$ & P04 & P04 & $\sqrt{ }$ \\
\hline 11. & $\begin{array}{l}\text { G01,G11,G12, } \\
\text { G13,G24,G26 }\end{array}$ & P05 & P05 & $\sqrt{ }$ \\
\hline 12. & $\begin{array}{l}\text { G02,G11,G22, } \\
\text { G24,G28 }\end{array}$ & P06 & P06 & $\sqrt{ }$ \\
\hline 13. & $\begin{array}{l}\text { G03,G04,G06, } \\
\text { G12,G20 }\end{array}$ & P03 & P03 & $\sqrt{ }$ \\
\hline
\end{tabular}

Dari data pengujian pada tabel 8 , peneliti hanya memberikan 13 data pengujian dari 39 data pengujian. Terdapat 36 data hasil dari pengujian sistem dan pakar yang hasilnya sama serta ada 4 data yang hasil nya berbeda. Data pengujian tersebut digunakan untuk menguji akurasi dari sistem. Dari data pengujian yang dilakukan pada sistem dan pakar, maka didapatkan perhitungan sebagai berikut:

$$
=\frac{36}{39} \times 100 \%=92,3 \%
$$




\section{SIMPULAN}

Berdasarkan dari hasil pembahasan, perhitungan, dan pengujian terhadap sistem pakar mendiagnosa penyakit ISPA menggunakan metode Naive Bayes maka didapat beberapa kesimpulan sebagai berikut.

1. Sistem pakar ini dapat membantu memberikan pemahaman kepada masyarakat mengenai penyakit ISPA seperti gejala, penyebab, dan solusi.

2. Dapat mendiagnosa jenis penyakit yang berhubungan dengan penyakit ISPA yang diderita masyarakat dengan memperlihatkan gejala-gejala yang ada.

3. Tampilan aplikasi yang sederhana dan dapat memberikan informasi tentang penyakit ISPA secara luas.

4. Memiliki tingkat akurasi sebesar 92,3\% dengan pengujian terhadap 39 data uji dan 104 data latih.

\section{DAFTAR PUSTAKA}

[1] M. Marlina, W. Saputra, B. Mulyadi, B. Hayati, and J. Jaroji, "Aplikasi sistem pakar diagnosis penyakit ispa berbasis speech recognition menggunakan metode naive bayes classifier," Digit. Zo. J. Teknol. Inf. dan Komun., vol. 8, no. 1, pp. 58-70, 2017, doi: 10.31849/digitalzone.v8i1.629.

[2] M. Bari, S. H. Sitorus, and U. Ristian, "Implementasi Metode Naive Bayes Pada Aplikasi Prediksi Penyebaran Wabah Penyakit Ispa (Studi Kasus: Wilayah Kota Pontianak," vol. 06, no. 2338-493X, pp. 205-214, 2018.

[3] Y. R. Nasution and Khairuna, "Sistem pakar deteksi awal penyakit tuberkulosis dengan metode bayes," Klorofil, vol. 1, no. 1, pp. 17-23, 2017.
[4] R. SUDIARTO, "Rancang Bangun Aplikasi Diagnosa Dini Terhadap Penyalagunaan Narkoba Menggunakan Metode Bayes Berbasis Web," J. Tek. Elektro, vol. 7, no. 01, pp. 45-51, 2017.

[5] M. Ilham Insani, A. Alamsyah, and A. T. Putra, "Implementation of Expert System for Diabetes Diseases using Naïve Bayes and Certainty Factor Methods," Sci. J. Informatics, vol. 5, no. 2, pp. 185193, 2018, doi: 10.15294/sji.v5i2.16143.

[6] D. J. S. Sako and J. Palimote, "A Medical Document Classification System for Heart Disease Diagnosis Using Naïve Bayesian Classifier," Int. J. Appl. Sci. Math. Theory, vol. 4, no. 1, pp. 69-79, 2018, [Online]. Available: www.iiardpub.org.

[7] M. Nilashi, M. Z. Roudbaraki, M. Farahmand, L. Branch, and A. Branch, "Journal of Soft Computing and Decision Support Systems A Predictive Method for Mesothelioma Disease Classification Using Naïve Bayes Classifier," vol. 4, no. 6, pp. 8-14, 2017.

[8] M. Syarief, N. Prastiti, and W. Setiawan, "Comparison of Naïve Bayes and Certainty Factor Method for Corn Disease Expert System: Case in Bangkalan, Indonesia," Int. J. Eng. Res. Appl. www.ijera.com, vol. 7 , no. 11 , pp. $30-34$, 2017, doi: 10.9790/9622-0711023034.

[9] H. GÖKER, "Çocukluk Çağı Dikkat Eksikliği ve Hiperaktivite Bozukluğunun Öngörülmesine Yönelik Dinamik Uzman Sistem Tasarımı," Bilişim Teknol. Derg., pp. 33-41, 2019, doi: 10.17671/gazibtd.458102. 
[10] G. Singh, K. Bagwe, S. Shanbhag, S. Singh, and S. Devi, "Heart disease prediction using Naïve Bayes," Int. Res. J. Eng. Technol., vol. 4, no. 3, pp. 4-6, 2017, [Online]. Available: https://irjet.net/archives/V4/i3/IRJE T-V4I3212.pdf.

[11] Hartatik, A. Purnomo, R. Hartono, and H. Munawaroh, "Naïve Bayes Approach for Expert System Design of Children Skin Identification Based on Android," IOP Conf. Ser. Mater. Sci. Eng., vol. 333, no. 1, 2018, doi: 10.1088/1757899X/333/1/012105.

[12] A. Pattekari, S.A.; Parveen, "Prediction system for heart disease using Naïve Bayes," Int. J. Adv. Comput. Math. Sci., vol. 3, no. 3, pp. 290-294, 2012.

[13] E. Y. Rachmawati, B. Prasetiyo, and R. Arifudin, "The Comparison between Bayes and Certainty Factor Method of Expert System in Early Diagnosis of Dengue Infection," Sci. J. Informatics, vol. 5, no. 2, pp. 159-170, 2018, doi: 10.15294/sji.v5i2.15740.
[14] Aristoteles, K. Adhianto, R. Andrian, and Y. N. Sari, "Comparative analysis of cow disease diagnosis expert system using Bayesian network and Dempster-Shafer method," Int. J. Adv. Comput. Sci. Appl., vol. 10, no. 4, pp. 227-235, 2019, doi: 10.14569/ijacsa.2019.0100427.

[15] I. Candra Dewi, A. Andy Soebroto, and M. Tanzil Furqon, "Sistem Pakar Diagnosa Penyakit Sapi Potong Dengan Metode Naive Bayes," J. Enviromental Eng. Sustain. Technol., vol. 2, no. 2, pp. 72-78, 2015 , doi: 10.21776/ub.jeest.2015.002.02.2.

[16] Indonesia. Kementrian Kesehatan Republik Indonesia.Direktorat Jenderal Pengendalian Penyakit dan Penyehatan Lingkungan."Pedoman pengendalian infeksi saluran pernapasan akut". Jakarta: Kementrian Kesehatan RI. 2011. 